\title{
Social Impact Of Tourism Development On Host Communities Of Osun Oshogbo Sacred Grove
}

\author{
Enemuo, Ogechi B \& Oduntan Oyinkansola C \\ 1)Enemиo, Ogechi.B (Department Of Hotel Management And Tourism, Michael Okpara University Of \\ Agriculture Umudike \\ 2)Oduntan Oyinkansola C (Department Of Hotel Management And Tourism, Michael Okpara University Of \\ Agriculture Umudike \\ Abia State, Nigeria.
}

\begin{abstract}
This work evaluated the social impact of tourism development on live of host communities of Osun Oshogbo scared grove in Osun State Nigeria. Social impacts of tourism are basically the consequences of either the development of the tourism industry or the presence of tourists in the destination. These impacts occur as a result of interaction between the host and the tourists. The objectives of the research were to identify the various attractions in the destination, evaluate the ways the destination has affected the social lives of the host communities and to determine how the impacts have affected the sustainability of local social lives of the host communities. Data for this research was generated using qualitative and quantitative techniques. Simple frequency percentages, mean and Analysis of variance (ANOVA) derived from regression analysis were used to analyse the data generated for the study. The findings of the analysis proved that tourism development had significant effect on the social lives of the host communities and tourism development had significant effect on the sustainability of the socio-cultural lives of the host communities. This implies that tourism has a significant effect on the social live and the sustainability of the social live of the host communities. Public participation must be encouraged by tourism developers and planners to ensure the sustainability of tourism development in the community. In conclusion, it is important that standard social frameworks must be established at the development stages to preserve and protect social and cultural values of Nigerian people most especially of the host communities.
\end{abstract}

Key words: Social, Impact, Tourism, Development and Host community.

\section{Introduction}

Tourism comprises of the activities of people travelling to and staying in places outside their usual environment, for not more than one consecutive year for leisure, business or other purposes (Holden, 2008). Wall and Mathieson (2006) defined tourism as "the study of people away from their usual habitat, of the establishment which responds to the requirement of travellers and of the impacts that they have on the economic, physical and social well being of their host". This definition recognises the key players in the industry as tourists (people who travel out of their usual place of residence), tourism industry (establishments that responds to the needs of travellers), impacts (economic, environmental, social and cultural) and the host community whose tourism resource the tourist have come to enjoy.

Tourism is based upon the economic and social processes and changes that are occurring in the environment of the societies where tourist come from, its development in destinations focuses on the use of natural and cultural resources which generates impacts. The environment is often referred to as the key component of tourism because it is the bedrock for any tourism development (Holden, 2008). The environment comprises of the home environment and the destination environment, this is because the relationship between tourism and the environment is concerned not just with the destinations that tourists go to but also the societies where they come from. The environment in which tourism occurs is the key component in tourism development (Holden, 2008). The attributes of an environment can either be viewed as natural and/or cultural. Tourism development takes place where the natural/ cultural environments are attractive and desirable. Rocks, mountains, streams, beaches, flora and fauna to mention but a few are examples of natural environment that attract large number of tourist. The cultural environment entails the part of the environment that is man-made and developed. The material component of cultural environment are purpose built structures and sites, caves, historical buildings, architectural features and ancient monument. The non-material components of the cultural environment are the culture of the people which entails the folklores, dance and carnivals.

Tourism destination is defined as a "country, state, region city or town which is marketed or markets itself as a place for tourists to visit" (Holloway, 2006). It is an area or resort with facilities and services that meet the need of the tourist. Tourist destinations consist of attraction, amenities and accessibility. The long term success of tourist destinations will be significantly enhanced if the benefits they offer are unique. It is 
worthwhile to note that the more benefits a place can offer, the greater the attraction of the destination. Multiple attractions provide added value and will improve the chance of a successful destination. Destinations depend on consumer demand and have lifecycles in which they experience a period of growth, expansion and eventually decline (Cooper, Fletcher, Gilbert \& Wanhill, 2008).

The community a tourist visits is often termed the host community. Cook, Yale and Marqua (2006) defined the host community as towns or cities that welcome visitors and provide them with the desired services. Smith (2001) also defined host communities as people who live in the vicinity of the tourist attraction and are either directly or indirectly involved with, and / or affected by the tourism activities. Tourism involves some elements of interaction between the tourist and the destination environment. The consequences of these interactions are often referred to as the 'impacts of tourism'. Most people think of tourism in terms of economic impacts, jobs and taxes. However, Kreag (2001) rightly pointed out that the range of impacts from tourism is broad and often influences areas beyond those commonly associated with tourism. Leaders as well as residents who understand the potential impacts of tourism can integrate this industry into their community in the most positive way.

The impacts of tourism can be sorted into several categories, the most common ones are; economic, environmental and socio-cultural impacts (Cook, Yale and Marqua, 2006). Each of these categories includes positive and negative impacts. Community and tourism developers must balance the opportunities and concerns of all stakeholders by working against conditions where positive impacts benefit one part of the community (geographic or social) and the negative impacts hurt another (Kreag, 2001).

The dense forest of the Osun-Oshogbo Sacred Grove, on the outskirts of Oshogbo, is one of the last remnants of primary high forest in southern Nigeria. It is regarded as the abode of Osun, the goddess of fertility, or the waters of life, one of the pantheons of Yoruba gods. Through the forest meanders the river Osun, and set within the forest sanctuary are Shrines, Sculptures and Art-works erected in honour of Osun and other Yoruba deities, many created in the past forty years by Suzanne Wenger and fellow New Sacred Art artists. The grove was recognised by United Nations Educational, Cultural and Scientific Organisation as a world heritage site in 2005.

Owing to the high level of income generated through tourism business, more attention has been given to the economic impact of tourism leaving the socio-cultural impacts that are also important aspects of the effects which are capable of sustaining or destroying tourism development. Tourism being an activity that involves the interaction of tourists and the hosts has impacts on the socio-cultural environment of the host communities. Since tourism has environment as the bed-rock for its development, environment in this context are the natural and cultural environment and being an activity that involves the interaction of the tourist with the cultural and natural environment, these interactions have impacts on the social live of the host communities. There should be a check on tourism development as it affects the social and cultural lives of the host community for sustainability to be achieved.

Purpose for the Study

The major objective of this research is to study the social impacts of tourism development on host communities of Osun Oshogbo sacred grove. The specific objectives of the study are to

Identify the various tourist attractions in Osun Oshogbo Sacred Grove.

Determine the impact of tourism development on the social lives of the host communities.

Evaluate the various ways the impacts have affected the sustainability of local social lives of the host communities.

Research Questions

What are the various tourism attractions in Osun-Oshogbo sacred grove?

What are the impacts of tourism development on the social lives of the host communities of Osun-Oshogbo sacred grove?

In what ways have the impacts of tourism development affected the sustainability of local social lives of the host communities of Osun-Oshogbo sacred grove?

\section{Methodology}

Area of study: The study was carried out in Osun Oshogbo Sacred Grove in Osun State. Osun State also known as "the state of living springs" is located on $7^{0} 30 \mathrm{~N}$ and $4^{0} 30 \mathrm{E}$ in Nigeria.

Research design:Survey design was considered most suitable for the study.

Population for the study

Oshogbo town consist of Oshogbo Local Government Area and Olorunda Local Government Area. The population of the study comprised 156, 691 (One hundred and fifty six thousand, six hundred and ninety one) and 131, 761 (One hundred and thirty one thousand, seven hundred and sixty one) people according to the 2006 National Population Census for Oshogbo and Olorunda Local Government Areas respectively.

\section{Sample for the study}


The two (2) Local Government Areas under study were purposively selected because they are the host communities of the tourism destination. Residents ranging form Eighteen (18) years and above of each strata of the population was proportionally sampled. This yielded a total of one hundred and eighty (180) respondents who formed the sample for the study. Ninety from Oshogbo and ninety from Olorunda.

\section{Instrument for data collection:}

The study employed qualitative and quantitative methods of data collection. The instruments used for the study were questionnaire and oral interview which was guided by interview schedule. The structured questionnaire was divided into three sections $\mathrm{A}, \mathrm{B}$ and $\mathrm{C}$ which seek information aimed at providing answers to the questions being considered in the study. The questionnaire used the likert scale with the following key;

5- Strongly agree

4- Agree

3- undecided

2- Strongly disagree

1-disagree.

\section{Data Analysis Techinque}

Simple descriptive statistics was used to analyse objective one on the identification of the various tourist attractions in the destination, Objective two which determines the impact of the destination on the social lives of the communities was analysed using the five point likert scale, simple descriptive statistics was used to analyse objective three on evaluating the various ways the impacts have affected the sustainability of the local social lives of the host communities.

\section{Results And Discussion}

Research question 1: What are the various tourist attractions in osun- Oshogbo sacred grove?

Table 1 Distribution of tourist attractions in Osun Oshogbo Sacred grove.

\begin{tabular}{lll}
\hline Options & Frequency & Percentage \\
\hline Sanctuaries and shrines & 176 & 97.8 \\
Sculptures & 162 & 90 \\
Traditional arts and crafts & 98 & 54.4 \\
Forest/groves & 92 & 51.1 \\
Theatres & 56 & 31.1 \\
Mountains & 14 & 7.8 \\
Historic buildings and monuments & 63 & 35 \\
Festivals & 180 & 100 \\
Local food & 42 & 23.3 \\
Others & 25 & 13.9 \\
\hline
\end{tabular}

Table 1 above showed that $97.8 \%$ of the respondents stated sanctuaries and shrines as tourist attractions in the destination, $90 \%$ stated that sculptures are tourist attractions in the destination, 54.4\% stated that traditional arts and crafts are tourist attractions in the destination, 51.1\% stated that forests are tourist attractions in the destination, $31.1 \%$ stated that theatres are tourist attractions in the destination, $7.8 \%$ stated that mountains are tourist attractions in the destination, 35\% stated that historic buildings and monuments are tourist attractions in the destination, $100 \%$ stated that festivals are tourist attractions in the destination, $23.3 \%$ stated that local foods are tourist attractions in the destination while $13.9 \%$ stated that there are other tourist attractions in the destination apart from those listed above.

Research question 2: determine the impact of tourism development on the social lives of the host communities

Table 2:

mpact of tourism development on the social lives of the host communities

\begin{tabular}{lllll}
\hline S/N & PERCEPTION OF IMPACTS & $\begin{array}{l}\text { TOTAL } \\
\text { SCORE }\end{array}$ & MEAN & DECISION \\
\hline 1. & $\begin{array}{l}\text { Tourism has created more employment } \\
\text { opportunities }\end{array}$ & 640 & 3.6 & Agreed \\
2. & $\begin{array}{l}\text { Tourism has increased income } \\
\text { 3. }\end{array}$ & 690 & 3.8 & Agreed \\
4. $\begin{array}{l}\text { Tourism has increased gambling has improved the housing } \\
\text { condition in the community }\end{array}$ & 604 & 2.6 & $\begin{array}{l}\text { Disagreed } \\
\text { Agreed }\end{array}$ \\
5. $\quad \begin{array}{l}\text { Tourism has improved the general } \\
\text { infrastructure in the community }\end{array}$ & 720 & 4.0 & Agreed
\end{tabular}


6. $\quad$ Tourism has helped to eradicate/reduce $395 \quad 2.2 \quad$ Disagreed drug abuse among the youths in the community

7. Prostitution has greatly increased due to

390 the influence of tourism

8. Tourism has improved the standard of living of the residents of the community

9. Tourism has improved public security within the community

10. Tourism has improved the quality of life of the people of the community

\begin{tabular}{lcc} 
Total & 5836 & 32.6 \\
Clustered mean & 3.3 \\
\hline
\end{tabular}

Table 2 above showed that the respondents agreed that tourism has created more employment opportunities, tourism, income, improved the housing condition in the community, improved the general infrastructure in the community, improved the standard of living of the residents in the community, tourism has improved the quality of life of the people of the community had 3.6, 3.8, 3.4, 4, 3.1, 3.8 and 3.9 means respectively. While respondents disagreed that tourism has increased gambling, tourism has helped to reduce/eradicate drug abuse among the youths in the community, that prostitution has greatly increased due to the influence of tourism had 2.6, 2.2 and 2.2 means respectively. This indicated that residents perceived the impacts of tourism as positive rather than negative considering the clustered mean of 3.3 (from the decision rule any mean response of 3.0 and above should be regarded as a positive impact).

Research question 3 : In what ways has tourism development affected the sustainability of local social lives of the host communities?

Table 3: Ways tourism development has affected the sustainability of local social lives

\begin{tabular}{lll}
\hline Option & Frequency & Percentage \\
\hline Creation of new jobs & 120 & 66.6 \\
Foreign earnings & 60 & 33.3 \\
Recognition of value systems & 35 & 19.4 \\
Social development & 102 & 56.6 \\
Economic breakthrough & 116 & 64.4 \\
\hline Others & 15 & 8.3 \\
\hline
\end{tabular}

Table 3 above showed that $66.6 \%$ of the respondents feel that tourism development has created new jobs, $33.3 \%$ stated that tourism development has affected their lives by creating foreign exchange earnings, $19.4 \%$ identified that tourism development has helped host communities to recognise their value systems, $56.6 \%$ stated that tourism development has contributed to social development, $64.4 \%$ stated that tourism has brought about economic breakthrough while $8.3 \%$ feel that tourism development has affected the sustainability of local social lives in ways other than those listed above.

HYPOTHESIS TESTING

Hypothesis One: Tourism development in Osun-Oshogbo sacred grove has no significant effect on the sociocultural lives of the host communities.

Table 4. Tourism Development and Socio-cultural lives of host communities

\begin{tabular}{llllll}
\hline & Sum of squares & Df & $\begin{array}{l}\text { Mean } \\
\text { Square }\end{array}$ & F cal & F tab \\
\hline Regression & 2.012 & 8 & 0.251 & $3.924^{* *}$ & 1.94 \\
Residual & 10.893 & 170 & 0.064 & & \\
Total & 12.905 & 178 & & & \\
\hline
\end{tabular}

Note: $* *$ is significant at $5 \%$

Decision rule: If $\mathrm{F}$ calculated is greater than $\mathrm{F}$ tabulated, then reject the null hypothesis and accept the alternate hypothesis.

Table 4 above showed that the F calculated was 3.924 while F tabulated was 1.94. Since F calculated is greater than F tabulated, the null hypothesis was rejected and the alternative hypothesis was accepted indicating that tourism development in Osun Oshogbo Sacred grove has significant effect on the socio-cultural lives of the host communities.

Hypothesis Two: Tourism development in Osun-Oshogbo sacred grove has no significant effect on the sustainability of the socio-cultural lives of the host community. 
Table 5 Tourism development and the effect on sustainability of social lives of host communities.

\begin{tabular}{lllccc}
\hline & Sum of squares & Df & $\begin{array}{l}\text { Mean } \\
\text { Square }\end{array}$ & F cal & F tab \\
\hline Regression & 6.558 & 8 & 0.820 & $5.563 * *$ & 1.94 \\
Residual & 25.051 & 170 & 0.147 & & \\
Total & 31.609 & 178 & & & \\
\hline
\end{tabular}

Note: $* *$ is significant at $5 \%$

Decision rule: if $\mathrm{F}$ calculated is greater than $\mathrm{F}$ tabulated, then reject the null hypothesis and accept the alternate hypothesis.

Table 5 above showed that the F calculated was 5.563 while F tabulated was 1.94 . Since the F calculated was greater than the F tabulated, the null hypothesis was rejected and the alternative hypothesis was accepted indicating that tourism development in Osun Oshogbo Sacred grove has a significant effect on the sustainability of social lives of the host communities.

\section{DISCUSSION OF FINDINGS}

Table 1 showed that tourist attractions in the destination were identified as sanctuaries and shrines, sculptures, festivals, forests and grove, traditional arts and craft which fall under cultural and natural environment. This is in line with the work of (Fakiyesi, 2008) that Nigeria possesses natural and cultural resources which are capable of attracting tourists. The festival was seen as a major tourist attraction in the destination by all the respondents. Majority of the respondents did not identify mountains as part of the tourist attractions in the destination. Also, majority of the respondents did not feel that tourists travel to their community or the tourism destination because of their local food. This compliments the work of (Aremu, 2001) that development and projection of Nigeria's natural and cultural remains the centrepiece of tourism awareness in Nigeria.

Table 2 showed the perception of social impacts by respondents. This indicated that the respondents perceived the impacts as desirable (positive) because the clustered mean of the overall responses was 3.3 which was higher than the decision rule that stated that any mean response above 3.0 should be regarded as a positive impact. Brunt and Courtney (1999) drawing from the social exchange theory stated that individuals will engage in exchange if the resulting rewards are valued and the perceived cost does not exceed the perceived rewards. The respondents viewed the rewards higher than the cost thus the positive impact.

Table 3 showed the ways tourism development has affected the sustainability of local social lives of the host communities. Respondents decided that tourism has changed their local social lives by creating new jobs $(66.6 \%)$, provided foreign exchange earnings (33.3\%), recognition of value systems (19.4\%), social development (56.6\%) and provided economic breakthrough (64.4\%), this is in accordance with cooper et al (2006) and Holloway (2006) that tourism is capable of stimulating economic growth, increasing the foreign exchange earnings of a country and creating new job opportunities.

Table 4 presented the first hypothesis of the research work which stated that tourism has no significant effect on the socio-cultural lives of the host communities. F calculated was greater than $\mathrm{T}$ tabulated (F cal $3.924>\mathrm{F}$ tab1.94) at 5\% significance level. The null hypothesis was rejected and the alternative hypothesis was accepted. This means that tourism has a significant effect on the socio-cultural lives of the host communities. From this study, the overall mean responses on the impacts of tourism on socio-cultural lives of the host communities was 3.3 (> 3.0) while the overall mean of responses on the impacts of tourism development on the cultural lives of the respondents was $3.7(>3.0)$ both indicated that tourism has affected the socio-cultural lives of the host communities positively.

Table 5 presented the second hypothesis of the research work which stated that tourism development has no significant effect on the sustainability of the socio-cultural lives of the host communities. F calculated was greater than F tabulated (F cal 5.563>F tab 1.94). The null hypothesis was rejected and the alternative hypothesis was accepted. This means that tourism development has a significant effect on the sustainability of the socio-cultural lives of the host communities. $93.3 \%$ of the respondents were of the opinion that tourism has promoted their indigenous culture, the influence of tourism on the awareness of religious festivals and pilgrimages had a cumulative mean response of 4.15 and the effect of tourism on the conservation of historic buildings and monuments had a cumulative mean response of 3.7. These figures indicated that the effects of tourism on the sustainability of their social lives are positive. However, the impact of tourism in creating new jobs is a negative effect where sustainability is involved as workers are likely to abandon their traditional business in favour of more lucrative employment in the tourism business. This compliments Ngoka \& Onyebinama (2008) which noted that tourism development tends to attract residents away from their traditional economic activities such as farming, fishing and traditional art and craft works (weaving, tye and dye, sculpture and carving works ). 


\section{Conclusion}

This work has attempted to evaluate the social impact of tourism development on host communities of Osun- Oshogbo scared grove, the major finding of the research led to the following conclusion:

1. Tourist attractions in Osun Oshogbo Sacred Grove consists of both natural and cultural resources which are capable of attracting large number of tourists and as such creating impacts on the host communities.

2. Tourism can contribute to social and cultural changes in host communities; this includes changes in standard of living and their social lives.

3. Negative social impacts have been under-researched due to the fact that it is often difficult to measure and to a large extent are indirect. These impacts are capable of threatening the survival of tourism destinations if measures and policies are not developed to address the negative issues.

\section{RECOMMENDATIONS}

The following recommendations were drawn from the findings of the research work.

1. Nigeria is a country that is rich in natural resources and cultural diversity. More destinations that can attract tourists should be developed as an alternative source of revenue to boost the Nation's economy and to preserve the natural and cultural resources of the country.

2. Tourism stakeholders should create awareness programs on the impacts of tourism especially the social impacts of tourism. This will help host communities to protect their traditional values and prevent the erosion of their cultural heritage.

3. Policies and practices that ensure the sustainability of the destination and the social lives of the host communities should be developed at the early stage of tourism development to avert the negative social impacts at the maturation of the industry.

4. Host community participation which is a pre-requisite for sustainable tourism development should be encouraged and facilitated in tourism development processes to give the host community a sense of ownership and control over the resources of the community.

\section{References}

[1.] Aremu, B. A. (2001). Cultural and Eco-Tourism Development in Nigeria. Ibadan: Hole publications.

[2.] Brunt, P. \& Courtney, P. (1999). Host Perception of Socio-Cultural Impacts. Annals of Tourism Research 26 (3): $493-515$.

[3.] Cook, R.A., Yale, L. J. \& Marqua, J. J. (2006). Tourism: The Business of Travel. $3^{\text {rd }}$ Edition. New Jersey: Prentice Hall.

[4.] Cooper, C., Fletcher, J., Fyall, A., Gilbert, D. \& Wanhill, S. (2008). Tourism: Principles and Practice. $4^{\text {th }}$ edition. New Jersey: Prentice Hall.

[5.] Fakiyesi, T. (2008). Economic Acceleration of Nigeria through the Development of Tourism industry. Retrived on 08/08/2010. Available on www.responsibletravel. org/resources

[6.] Holden, A. (2008). Environment and Tourism. $2^{\text {nd }}$ edition. Canada: Routledge.

[7.] Holloway, C. (2006). The Business of Tourism. $7^{\text {th }}$ edition. England: Prentice hall.

[8.] Kreag, G. (2001). The Impacts of Tourism. Retrieved on 16/05/2010. Available on http://www.seagrant.umn.edu/tourism/pdfs/ImpactsTourism.pdf

[9.] United Nations Educational Cultural and Scientific Organisation. (2005). Osun Oshogbo Sacred Grove. Retrieved on 08/08/2010. available on whc.unesco.org /en/list/1118/

[10.] Smith, S. L. (2001).Measuring the Economic Impact of Visitors to Sport Tournament and Special Events. Annals of Tourism Research 28(3) 829-31.

[11.] Wall, G. \& Mathieson, A. (2006). Tourism: Change, Impacts and Opportunities. England: Prentice Hall. 